\title{
How to Strengthen Irish Studies throughout Europe? A Diagnosis Based on the German-Speaking Countries
}

\author{
Jochen Achilles \\ University of Würzburg, Germany
}

Copyright (c) 2018 by Jochen Achilles. This text may be archived and redistributed both in electronic form and in hard copy, provided that the author and journal are properly cited and no fee is charged for access.

\begin{abstract}
Against the background of the larger European situation, this essay will primarily concern itself with the positioning of Irish Studies within the German and Austrian university system. It will also focus on the institutional basis of Irish Studies within German English departments and on career options for scholars specializing in Irish Studies. This survey reveals a surprising discrepancy between, on the one hand, the substantial research and instruction in Irish Studies taking place in German-speaking countries and, on the other, the deplorable institutional situation and non-existent career options. In some respects Irish Studies in other European countries face similar problems. With regard to forming associations and launching periodicals, however, efforts have been made elsewhere in Europe, which German-speaking countries would be well-advised to adopt. Some of these initiatives will be described in the hope that such an assessment will trigger a larger debate.
\end{abstract}

Key Words. Survey of research and teaching, self-definition, Postcolonial Studies, European Studies, institutionalization, relevance.

Resumen. Teniendo como marco general de referencia el estado de la cuestión en Europa, este artículo se centrará principalmente en la situación de los Estudios Irlandeses en los sistemas universitarios alemán y austriaco. Igualmente se examinará el aspecto institucional de los Estudios Irlandeses dentro de los departamentos de inglés en Alemania, así como las perspectivas profesionales de los académicos que se especializan en este campo. Este estudio destaca, por encima de todo, la enorme discrepancia existente entre el abuntante corpus de investigación, y su correspondiente docencia, sobre Estudios Irlandeses que tiene lugar en los países en los que el alemán es la lengua dominante, por un lado, y el deplorable panorama institucional en lo que se refiere a salidas profesionales. En cierta medida, en otros países europeos los Estudios Irlandeses se enfrentan a problemas similares. Con respecto a la creación de asociaciones y a la edición de revistas especializadas, sin embargo, hay que destacar los avances realizados en este apartado en algunos países europeos que, sin embargo, no han tenido un paralelismo en los países de habla alemana. A continuación se describirán algunas de estas iniciativas con el objetivo de que dicho análisis sea el inicio de un fructífero debate sobre el tema. 
Palabras clave. Estudio sobre investigación y docencia, autodefinición, estudios poscoloniales, estudios europeos, institucionalización, relevancia.

\section{Introduction}

Against the background of the larger European situation, this essay will primarily concern itself with the positioning of Irish Studies within the German and Austrian university system. It will also focus on the institutional basis of Irish Studies within German English departments and on career options for scholars specializing in Irish Studies. This survey reveals a surprising discrepancy between, on the one hand, the substantial research and instruction in Irish Studies taking place in German-speaking countries and, on the other, the deplorable institutional situation and non-existent career options. While research and instruction appear very lively, there are hardly any larger institutional patterns recognizable that might provide visibility and recognition. In other words, Irish Studies do happen at German universities. But with very few exceptions they largely pass unnoticed. In some respects both the problems and perspectives of Irish Studies in German-speaking countries resemble those of other European nations. With regard to forming associations and launching periodicals, however, efforts have been made elsewhere in Europe which German-speaking countries would be well-advised to adopt. Some of these initiatives will be described in the hope that such an assessment will trigger a larger debate.

\section{Irish Studies in German-Speaking Countries: Teaching and Research Survey}

In 1995, the Journal for the Study of British Cultures published a volume on Irish, Scottish and Welsh cultures. Whether they were considered British cultures remained open. In this volume I contributed a survey of Irish Studies in Germany to an article misleadingly called "The Study of British Regions from Germany", which also dealt with German Scottish and Welsh Studies (Achilles, Drescher and Harvie). Exactly twenty years ago, at the first Limerick Conference in Irish-German Studies, titled Irish-German Connections: Culture, Business, Politics, Heinz Kosok gave the opening talk titled "Irish Literature and Irish Studies in Germany" on September 4, 1997, which was published a year later in the conference proceedings. Both these surveys, yielding similar results, stand at the beginning of the period under scrutiny now.

In my 1995 article I distinguished between three historical paradigms of Irish history, culture and literature: the colonial paradigm into the eighteenth century, the nineteenth- and early twentieth-century nationalist and the more recent intercultural paradigm since the sixties of the last century. German scholars contributed to the study of writers in all three periods (Achilles, Drescher, and Harvie 200-03). I particularly emphasized the diversity and multiplicity of approaches in German Irish Studies of the 1980s and early 1990s, ranging

from articles, doctoral dissertations, studies of individual authors and genre studies (Lubbers 1985) to a history of Irish literature (Kosok 1990), from authors like Wilde, Joyce and Beckett to writers like Lady Morgan (Schoner 1983), Somerville \& Ross (Huppertsberg 1980) and Fitzmaurice, from the discussion of the Irish metafictional tradition of Sterne, Flann O'Brien and John Banville (Imhof 1986 and 1989) to the lively theory and practice of the Tübingen Anglo-Irish Theatre group (Bort 1993) and numerous annotated editions of important Irish texts, designed for the curricula 
of German secondary education (Lubbers 1985, Imhof 1987, Kosok 1989). (Achilles, Drescher and Harvie 204; for bibliographical information, see 206-208)

In the 1970s, 80s, and early 90s, Irish Studies obviously began to flourish in Germany. The names of some scholars and their universities loom particularly large, as they initiated developments of relevance for the decades to come. Among them is Heinz Kosok, in those years often called O'Kosok for his untiring efforts to strengthen German Irish Studies and to turn the University of Wuppertal into their central institution. He hosted the first IASIL conference in Germany there in 1981. A second Irish Studies Centre, initiated by Klaus Lubbers, began to flourish at the University of Mainz. Both Kosok and Lubbers published important books in the field, Kosok a seminal study on Sean O'Casey and a history of Irish literature, and Lubbers a pioneering history of the Irish novel in the nineteenth century. At the universities of Wuppertal and Mainz they built up substantial Irish Studies libraries, probably still the best in the country. They also encouraged and supervised the work of a then new generation of German scholars dedicating themselves to Irish Studies, such as Rüdiger Imhof, Werner Huber and myself.

As far as research is concerned, the interest in Irish Studies seems to have even increased since. While the "IASIL Bibliography Bulletin for 1996" lists 64 publications by scholars from German-speaking countries, this number has more than doubled in recent years. The IASIL bibliographies for 2014 and 2015 list 123 and 140 titles, respectively, from the German-speaking part of the world. While research interest with regard to giants such as Swift, Joyce, Yeats and Beckett remains relatively consistent, there is much more fluctuation in the quantity of criticism on more recent authors like Heaney, Friel or McDonagh. While pioneers, such as Rolf Breuer, Klaus Peter Jochum, Heinz Kosok, Eckhard Lobsien, Hermann J. Real and Fritz Senn, keep publishing in their respective fields of Beckett, Joyce, Shaw, Swift and Yeats studies, there is also an increasing number of articles and books, often published doctoral dissertations, by scholars not programmatically associated with Irish Studies. In 2010 two histories of literature were published in Germany which mention Ireland in their titles (Nowak; Wagner). In the same year Martin Middeke and Peter Paul Schnierer co-edited The Methuen Drama Guide to Contemporary Irish Playwrights. In the context of an interdisciplinary Viennese research project on the reception of English-language drama in Vienna (Weltbühne Wien: Die Rezeption englischsprachiger Theaterstücke auf Wiener Bühnen im 20. Jahrhundert) publications appear, which discuss Irish drama in this international and transcultural context.

This is indicative of a more general phenomenon. Embedding Irish Studies in intercultural, both European and global contexts is a powerful trend in recent years that is also markedly noticeable in German Irish Studies. There are publications on Ireland and the Irish in Germany (O'Reilly and O'Regan), on The Irish Context of 'Kristallnacht' (Holfter) and on cultural and literary translators (Egger). There is a study on Beckett and philosophy, which contains considerations of Beckett's relation to Gottfried Wilhelm Leibniz's Monadology (Ackerley) and Arthur Schopenhauer's thought (Tonning). There is an essay on the reception of Synge's and O'Casey's plays in Vienna from WW I to the end of the nineteen-sixties (Fuchs). There is even a doctoral dissertation that attempts an eco-critical comparison between Joyce's Ulysses and Twain's Huck Finn (Liu). All of these projects demonstrate both the lively interdisciplinarity and the intercultural perspectives of German Irish Studies, which connect them with Irish Studies elsewhere.

As far as teaching Irish Studies in Germany is concerned, the development is not quite as positive. In his 1998 survey of the course programs of German English departments Kosok concludes that in the academic year of 1996/97, comprising two semesters, 56 out of 68 German English departments offered at least one or two courses on Irish literature and/or 
culture, "some 150 courses altogether, which is not a bad result" ("Irish Literature" 25). 32 offerings are cultural studies and history courses, 36 courses on literary genres or periods and 79 courses on individual authors (26). ${ }^{1}$ The Annual Report on English and American Studies (AREAS) for the winter semester 2012/13 tells a somewhat bleaker story. Out of 75 English departments only $23-21$ in Germany and 2 in Austria - list Irish Studies courses. In terms of institutions Irish Studies representation has been more than halved since 1996/97. ${ }^{2}$ This can also be said of the numbers of courses taught. While Kosok lists rougly 75 courses per semester in 1996/97, AREAS 2012/2013 counts only 36 courses overall, 11 cultural studies and history courses, 9 courses on literary periods and genres and 16 courses on individual authors. Out of the 36 courses listed, 10 pursue comparative angles. They offer Joyce together with Woolf and Faulkner, for example. This often means that the Irish authors are not considered as such but as representatives of modernism in the case of Joyce or of decadence in the case of Wilde, who is almost equally popular. This reduction of the teaching of Irish Studies at universities in German-speaking countries stands in contrast to the much better research situation. While research seems to be numerically stronger than ever, teaching seems to have declined.

\section{The Relevance of Irish Studies and the Question of Self-Definition}

As the numbers of publications and courses demonstrate, the development and present state of Irish Studies in Germany is certainly not wonderful and may be considered crying out for improvement. Germany: Looking In, Looking Out, a 2015 paper by the Institute of International and European Affairs (IIEA), a Dublin-based think tank, paints a totally devastating picture, however:

After a remarkable interest in Irish Studies in the 1970s and 1980s in German
universities, the area has gone into near terminal decline. ... The reasons for this
decline are manifold and for the most part of a structural nature; there is no evidence
that the popular interest has waned, in fact, on the contrary, judging by tourist
numbers it is increasing. We have now reached a situation where among the hundred
or so German universities, not a single one displays any serious interest in Ireland.
The disappearance of Ireland as a study area from German universities should be of
concern for all those who work towards better mutual understanding. Serious
consideration might be given to redressing this imbalance. (Meenan 8)

As the above brief and sketchy survey shows, Irish Studies have not really and in earnest disappeared from German universities but they seem to have become all but unnoticeable. There is a stark discrepancy between the actual and demonstrable scholarship in, and the almost complete institutional invisibility of, German Irish Studies.

This may have to do with the position of Irish Studies within the large academic field of Englishes and their literatures and cultures, in which a variety of nations and regions compete for academic positions and budgets within English Departments. In his 1998 survey Kosok suggests that, after the demise of nationalist paradigms, Irish literature as the oldest of the postcolonial literatures in English may "serve as a model for the discussion of all other literatures that have emerged, in more recent times, from a colonial past" (24; see 23-25). He concedes himself that this idea, as plausible as it may be, "contains a certain degree of wishful thinking" (25). In hindsight, it is safe to say that, as far as Germany is concerned, this wish did simply not come true. Professorships for the New English Literatures at German universities have not been filled with Irish Studies experts. Although the website of the German Association for Anglophone Postcolonial Studies (GAPS, formerly GNEL and 
ASNEL), founded in 1989, lists "European regions ... especially at the margins of a dominant culture as in Ireland or Scotland" after other regions from "Africa, the Caribbean, South Asia, Canada, Australia, New Zealand and the Pacific", the 2017 annual GAPS conference largely addresses Africa and Australia. This is not different from such conferences in the nineties I remember as an attendant and speaker on matters Irish. My dominant impression then was that Irish culture, precisely because its struggle for independence precedes nations and regions outside Europe, is considered not a model but an exception in the postcolonial context.

In his 2014 essay on the world of Irish Studies and their symbolic positioning between Boston and Berlin, Joachim Fischer argues for abandoning the postcolonial paradigm and for embracing a Europe-oriented one instead. Fischer holds "often romantically-inspired Hibernophiles in continental universities, especially in Germany", who "were all too ready to ape the postcolonialism of their Anglo-American theoretical masters" (87), presumably Edward Said and others, responsible for this lack of European awareness. Beyond the allegedly spineless subservience of German scholars to Ivy League-inspired postcoloniality, another problem with substituting a European for a nationalist or postcolonial paradigm of Irish identity remains the absence of clear contours of what European identity actually means. The border between the Republic and Northern Ireland as a touchstone of the relationship between the EU and Brexit Britain is only the latest complication. Shape-shifting Kathleen ni Houlihan may still seem more attractive and less elusive to some. Both In High Germany (1990) and The Parting Glass (2010), Dermot Bolger's plays set in Germany, Ireland and partly in France, which try to assess artistically the development of Irish identity since the nineties and which Fischer also addresses (89), highlight the fleeting and evanescent qualities of both contemporary Irishness and Europeanness. Discussing Bolger's drama, Fintan O'Toole describes the dilemma when he comments on the Irish situation: "Ireland itself is the product of dreams - the dreams of Independence first, then the dreams of modernity, the American dreams of high-tech foreigners coming to make all the failures right" (5). With regard to European identity he diagnoses a similar shapelessness and intangibility:

The very restlessness, the shifting, open, unformed nature of the world of these plays, makes them also European. Here we have not just an unofficial Ireland but also an unofficial Europe, the Europe of the Gastarbeiter and the long-haul truck driver, the Europe of the football hooligan and the border guard. . . . If they belong anywhere, these plays belong to the Europe that is now stretching itself untidily from Connemara to the Caucasus, trying to find a comfortable place to lay its increasingly uneasy head. (6)

I agree with Fischer that the very changeability of contemporary Europe demands research and deserves the foundation of multilingual European Studies Departments, too few of which exist as yet. I do not think, however, that this would necessarily improve the academic standing of Irish Studies, which can be ostracized as part of European Studies just as well as they can be ostracized as part of postcolonial studies.

\section{The Institutionalization of Irish Studies in German-Speaking and Other European Countries}

Whether in a Bostonian postcolonial or a Berlinesque European context, forms of the institutionalization of Irish Studies are all-important. An influential move in the direction of the Europeanization of Irish Studies was the foundation of EFACIS, the European Federation of Associations and Centres of Irish Studies in 1996. EFACIS publishes both Irish Studies in 
Europe, a peer-reviewed book series covering Irish cultural studies in the broadest sense, and RISE, Review of Irish Studies in Europe, a peer-reviewed journal which also devotes itself to matters Irish, ranging from literature and history to politics and visual culture. EFACIS is essentially an umbrella organization of national Associations and regional Centres. Centres can be formed by at least five EFACIS members, academics from different disciplines, students and/or enthusiasts of Irish culture. They can be situated locally at one university or regionally organized by two or more universities. Since 2013 EFACIS organizes what is called the Irish Itinerary, tours of Irish authors, artists and performers in series of coordinated cultural events at such centres. Harking back to the way in which medieval Irish missionaries brought Christianity to the continent, the Irish Itinerary thus introduces and disseminates forms of contemporary more secular Irish culture to EFACIS Centres around Europe. In such ventures co-operations with and support by Culture Ireland, an organization that promotes professional Irish artists and arts organizations internationally, and the Irish Film Institute, which both provides films and negotiates interviews with directors, are possible.

These interlinked networks, developed over the last twenty years and usable by national or regional incentives, have not (yet) substantially improved the institutional situation in the German-speaking countries. At the 2012 Potsdam Anglistentag, the annual German English Studies conference, the fledgling attempt to hibernicise German English Studies by the foundation of a German Association of Irish Studies led to little more than a list of names (Heinz et alii 9). Wuppertal and Mainz, the two former strongholds of German Irish Studies from the 1970s to the 1990s, have grown considerably weaker than they were. In Mainz only the good library of rare first editions and primary sources has remained of Klaus Lubbers's Irish Studies efforts there. In recent years an abortive attempt was made to install a junior professorship for Irish Studies, which fell victim to a redefinition of research priorities. In Wuppertal the institutional groundwork of Irish Studies, laid by Heinz Kosok, with Rüdiger Imhof's additional professorship for Irish Studies, has shrunk to just one professorial position officially devoted to English literature. It is due to the personal engagement in and devotion to Irish Studies of Katharina Rennhak, the current holder of this professorship, that Wuppertal still strongly represents Irish Studies in Germany. She publishes widely in the field, currently supervises four $\mathrm{PhD}$ dissertations on Irish topics and is very active internationally in both EFACIS and IASIL. At the Wuppertal Walter Macken Archive, acquired by Heinz Kosok in the late seventies, Rennhak organized the centenary symposium in 2015. Another German EFACIS Centre is located in Saarbrücken, a cooperative effort of Joachim Frenk, the Chair of British Literary and Cultural Studies, and the German-Irish Society Saarland, which was founded in 2010 when the English Department introduced an Irish semester. Ever since guest lectures, seminars, introductions to British and Irish cultural studies, one PhD project as well as film screenings and outreach projects to the community accentuate the Saarbrïcken focus on Ireland. There is one more German center with a special focus, the Ehrenpreis Center for Swift Studies at the University of Münster, founded by Hermann J. Real and Heinz J. Vienken in 1986, which houses book collections and working papers, organizes symposia and publishes profusely on the Dean.

The most active and visible Center for Irish Studies in the German-speaking world is in Vienna. Werner Huber, who unexpectedly, very prematurely and extremely regrettably died last year, founded it in 2009. With the help of several lecturers, among them Dieter Fuchs, Huber, developed the Centre into an impressive research and outreach unit. It is based on the cooperation of the Republic of Ireland, represented by the Irish Embassy, and the University of Vienna, both providing matching funds. These funds are used for a triennial Distinguished Chair Program that brings Irish luminaries to Vienna to teach for one semester. The rest of the budget goes into additional guest lectures and cultural events that reach out to the community. The Vienna Centre for Irish Studies organized an impressive string of 
conferences, supplemented by distinguished Lecture Series. In 2013 the Centre also organized an intercultural exhibition for the wider public on the integration of Irish emigrants in central Europe: "Strangers to Citizens: The Irish in Europe, 1600-1800 / Auswanderer werden Mitbürger: Die Iren in Europa 1600-1800". The Vienna Irish Studies \& Cultural Theory Summer School 2017 is the most recent endeavor. The Vienna Centre for Irish Studies also initiated many publications in the field and contributes substantially to the book series Irish Studies in Europe.

It makes sense to cast an envious eye beyond for a brief look at Centres for Irish Studies outside the German-speaking countries, which may perhaps serve as models in the German context. Different from the German situation, the humanities in several European countries have managed to establish national organizations for the study of Irish literature, culture, history and politics. All of these associations organize conferences and further research projects by providing networks for debate and mutual support. Some also publish journals. Often these journals accept contributions in the language of the journal's respective home country in addition to English or Irish, thus paying tribute to regionalism and transnationalism at the same time.

The Scandinavian countries have joint forces in NISN, the Nordic Irish Studies Network, which organizes seminars, symposia and biennial conferences. It also launches joint research projects of scholars based in Nordic countries. In this context Nordic Irish Studies Journal, an annual, peer-reviewed print periodical, aims at de-hibernicising and thereby internationalizing the perspective on Irish Studies. BAIS, the British Asssociation for Irish Studies, frequently holds conferences, provides financial support for research projects by young scholars and organizes an essay competition. The (relatively low) membership fee includes a subscription of the Irish Studies Review, a multi-disciplinary print quarterly. SOFEIR, la Societé Française d'Études Irlandaises (the French Society for Irish Studies), organizes an annual conference in addition to symposia and workshops, offers research scholarships and publishes Études Irlandaises, a both multidisciplinary and multilingual journal, accepting articles in English, Irish and French. AEDEI, Asociación Española de Estudios Irlandeses (The Spanish Association for Irish Studies), holds annual conferences, awards grants, and publishes Estudios Irlandeses, the annual, peer-reviewed, open access, electronic periodical you are just reading.

Italy boasts a sizeable number of Centres for Irish Studies, including Florence, Palermo, Perugia, Rome, Sassari, Trieste and Turin. In addition Florence University Press publishes Studi irlandesi: A Journal of Irish Studies, another annual, peer-reviewed and openaccess periodical, which particularly encourages contributions by young scholars and is willing to provide an international forum for both completed projects and work in progress. Centres for Irish Studies in both Czechia and Hungary are also very strong and active. Among them is the Prague Centre for Irish Studies with a focus on modern Irish literature and an ongoing research project on James Joyce as well as Hungarian Centres in Budapest, Debrecen and Pécs. In all these locations scholars such as Ondřej Pilný in Prague, Michael McAteer in Budapest, Mária Kurdi in Pécs and Csilla Bertha with Donald Morse in Debrecen have for many years done pioneering work in establishing Irish Studies across Europe. ${ }^{3}$ All these substantial and encouraging European efforts demonstrate that the growth and development of European Irish Studies are not impossible. Networks on both the European and national level are in operation and a growing number of increasingly electronic journals provide platforms for scholarly debate. With regard to such forms of institutionalization Irish Studies in German-speaking countries obviously lag behind.

Two as yet unmentioned institutions, one in Leuven, Belgium, and another one in Liverpool, England, deserve special attention, as they realize unusual options. The Leuven Centre for Irish Studies (LCIS) was founded in 2010 by Hedwig Schwall, Elke d'Hoker and 
others. It is based on a cooperation between the Catholic University of Leuven and the Leuven Institute for Ireland in Europe, located in the beautifully renovated Irish College. The LCIS can build on historical Irish itineraries of Franciscan monks who came to Leuven in the early seventeenth century. Its objectives are to foster interdisciplinary research, the international cooperation of scholars and the promotion of cultural events. The LCIS distinguishes three broad research areas: 1. Literature, History, Theology, Philosophy and Fine Arts, 2. Peace and Transformative Growth, 3. Economics, Business, Law, Innovation and Valorization. Bringing together literary and cultural studies from Irish pilgrimages to Irish short stories, psychosocial trauma and transformation research as well as the study of trade patterns within European integration, the Leuven Centre is unique and hopefully trendsetting. The Liverpool Institute of Irish Studies, which teaches, studies and researches peace, conflict and social justice as well as Irish history and literature, was awarded the Blair Chair by the Irish Government in 2007. Its $£ 5$ million endowment honors the supportive role of Tony Blair in the peace process leading up to the Good Friday Agreement. Peter Shirlow, the present chairholder, is fittingly an expert on conflict transformation and social justice.

Both the Leuven Centre and the Liverpool Institute with its Blair Chair benefit from special historical and topographical conditions, which cannot easily be transferred and reproduced elsewhere. But both the exceptionally comprehensive interdisciplinarity of Leuven and the institutionalization of endowed professorships for Irish Studies as in Liverpool are mandatory for the international development of Irish Studies. This is especially true for countries like Germany with no recognizable Irish diaspora. A professorship for Irish Studies at one of the German universities with a more or less submerged tradition in the field could help develop an interdisciplinary research field and a convincing Centre from which an Irish itinerary might begin to develop other such centres. Such a professorship could more realistically be based on matching funds than on a large endowment from the Irish government alone as in Liverpool. The Vienna Centre is a model in this regard. But more stability and permanence in addition to more money are needed.

In order to not only produce substantial teaching and research but also to emanate visibility and recognizability, European Irish Studies need institutional platforms. In the German university system, however, Irish Studies are not really a career option. To qualify for professorial positions in German English Departments usually two books are needed, the published doctoral thesis and a second book, which is traditionally also the result of a supervised process called Habilitation. Choosing an Irish topic for both these projects amounts to a form of academic suicide, as there are no professorships for Irish Studies - with the exception of the Wuppertal professorship that has meanwhile been redefined and thereby vanished as such - and as professorships for the New English Literatures are habitually not filled by Irish Studies scholars. To my knowledge only three people in Germany wrote both these required publications on Irish topics: Werner Huber, Bernhard Klein and myself. ${ }^{4}$ Among younger scholars Michaela Schrage-Früh wrote her first book completely and the second one largely on Irish authors. Ingo Berensmeyer, Dieter Fuchs, Christian Huck and Gerold Sedlmayr wrote their doctoral dissertations on Irish subjects and continued by studies in central areas of English literature and culture. Sarah Heinz, recently appointed Werner Huber's successor in Vienna, wrote her doctoral thesis on AS Byatt and her Habilitationsschrift on whiteness in contemporary Irish literature and film. There is currently one more second book in Irish Studies in the making as far as I know, Alessandra Boller's Marburg study of the Irish short story as an emergent national genre. As yet none of these research efforts lead to academic positions defined as Irish Studies.

Such structural factors may partly explain why the sizeable German contribution to teaching and research in Irish Studies is compatible with the judgment by the Institute of International and European Affairs that in Germany "the area has gone into near terminal 
decline" (Meenan 8). In the German academic environment you can have an interest in Irish Studies and pursue it up to a point, but you better do not try to build a career on this interest. You can also be involved in Irish Studies without defining yourself as an Irish Studies scholar. As a Joyce expert you can either pursue an Irish Studies approach and discuss, say, the quality of the Guinness in Mulligan's as a motivating force in "Counterparts" or you can be differently motivated and alternatively analyze neuroscientific aspects of Molly Bloom's stream of consciousness in Ulysses. Your self-definition as a scholar of Irish Studies or Modernism may depend on such priorities.

Not as a practice but as a discipline Irish Studies are well-nigh invisible in the German-speaking world. Against the background of lively national associations, research networks and journals in other European countries this seems to some extent anomalous. Without a recognizable self-identity, an entity remains imperceptible. Esse est percipi, Bishop Berkeley famously opined. Therefore both the Irish and German governments and university administrations would be well advised to end such submersion by an incentive towards the institutionalization of Irish Studies. Co-funded permanent lecturer- and professorships, channeling existing expertise, would put Irish Studies on the map as a visible and highly productive interdisciplinary academic field, which would tremendously enhance both the attraction of Irish Studies for German students and the perception of Ireland in Germanspeaking countries. In the last analysis, such changed perceptions also translate into improved economic relations. Anybody listening?

\section{Notes}

\footnotetext{
${ }^{1}$ Discussing the German translation of Irish literature and the reception of Irish drama on German stages as well as reporting on the German Book Fair in 1996, which foregrounded Irish literature, Kosok adds valuable information on the ways in which the German image of Ireland was shaped outside academia (Kosok, "Irish Literature" 27-32).

${ }^{2}$ There may be fluctuation in both the course offerings and research production which may have evaded me. My discussion and accentuation of German research projects and researchers in Irish Studies is also selective and based on my specific perception of the field. I apologize to anybody who feels undeservedly left out. What I can offer here is a hopefully informed impression rather than an exhaustive scrutiny.

${ }^{3}$ Again this is just a rough sketch. It is far from a complete list of Centres for Irish Studies in Europe and even less of scholars devoting themselves to this field. Again I apologize to any institution or person I should have included but did not. On the EFACIS website a list of all the Centres can be accessed.

${ }^{4}$ Rüdiger Imhof, who held the Wuppertal professorship for Irish Studies, wrote his dissertation on the dramatic technique of Harold Pinter and his Habilitation on contemporary metafiction in English since 1939. Numerous other books and articles established him as a leading Irish Studies scholar. Emer O'Sullivan is a Professor of English Literature who specializes in children's literature and also devotes herself to Irish children's literature in her teaching and research.
}

\section{Works Cited}

Achilles, Jochen. Drama als problematische Form: Der Wandel zu nichtrealistischer Gestaltungsweise im Werk Sean O'Caseys. Frankfurt am Main: Lang, 1979.

. Sheridan Le Fanu und die schauerromatische Tradition: Zur psychologischen Funktion der Motivik von Sensationsroman und Geistergeschichte. Tübingen: Narr, 1991. 
Horst W. Drescher and Christopher Harvie. "The Study of the British Regions from Germany". Journal for the Study of British Cultures 2.2 (1995): 201-17.

and Rüdiger Imhof, eds. Irische Dramatiker der Gegenwart. Darmstadt: Wissenschaftliche Buchgesellschaft, 1996.

Ackerley, Chris, "Monadology: Samuel Beckett and Gottfried Wilhelm Leibniz". Beckett/Philosophy. Eds. Matthew Feldman and Karim Mamdani. Stuttgart: Ibidem, 2015. 185-210.

Berensmeyer, Ingo. John Banville: Fictions of Order. Authority, Authorship, Authenticity. Heidelberg: Winter, 2000.

- 'Angles of Contingency': Literarische Kultur im England des 17. Jahrhunderts. Tübingen: de Gruyter, 2007.

Bolger Dermot. "In High Germany”. A Dublin Quartet. Intr. by Fintan O'Toole. Harmondsworth: Penguin, 1992. 71-109.

. The Parting Glass: A Play. Dublin: New Island, 2011.

Boller, Alessandra. From the Nineteenth Century Tale and Sketch towards the Short Story as Ireland's 'National Genre': Tracing the Intertwined Developments and Dynamics of an Emerging Irish Literary Market, Nationalist Discourses, and the Beginnings of the Irish Short Story in their Cultural Contexts. Habilitationsschrift Marburg. Work in progress.

Bort, Eberhard, ed. "Standing in their shifts itself...": Irish Drama from Farquhar to Friel, Bremen: European Society for Irish Studies, 1993. Print.

. The State of Play: Irish Theatre in the Nineties. Trier: WVT, 1996. Print.

Breuer, Horst. Samuel Beckett: Lernpsychologie und leibliche Determination. München: Fink. 1972.

Breuer, Rolf. Die Kunst der Paradoxie: Sinnsuche und Scheitern bei Samuel Beckett. München: Fink, 1976.

, Harald Gundel and Werner Huber, eds. Beckett Criticism in German: A Bibliography. München: Fink, 1986.

Duggan, Jennifer. "A Portrait of the Prime Minister as a Young Man”. Time. 24 July, 2017. 22-25.

Egger, Sabine, ed. Cultural/Literary Translators: Selected Irish-German Biographies II. Irish-German Studies 9. Trier: WVT, 2015.

Fischer, Joachim. "Boston or Berlin? Reflections on a Topical Controversy, the Celtic Tiger and the World of Irish Studies". Irish Review 48 (2014): 81-95.

Fuchs, Dieter. Joyce und Menippos. 'A Portrait of the Artist as an Old Dog'. Würzburg: Königshausen \& Neumann, 2006.

"The Reception of Synge's and O'Casey's Plays in Vienna from 1914 - 1969". Anglo-German Theatrical Exchange: "A Sea-change into Something Rich and Strange?" Eds. Rudolf Weiss, Ludwig Schnauder and Dieter Fuchs. Amsterdam: Rodopi Brill, 2015. 87-128.

. Elizabethan Revenge Drama - Cultural Representations, Signifying Practices and the Rise of Reformation Discourse. Habilitationsschrift Vienna. Forthcoming.

Heinz, Sarah. Die Einheit in der Differenz: Metapher, Romance und Identität in AS Byatts Romanen. Tübingen: Gunter Narr, 2007.

. The Relative Skin: Whiteness in Contemporary Irish Literature and Film. Habilitationsschrift Mannheim 2013.

et alii. "Recent Ireland; Visions and Revisions of Irishness from the 1990s to Today: Introduction". Anglistentag 2012: Proceedings. Eds. Katrin Röder and Ilse Wischer. Trier: WVT, 2013. 3-10. 
Holderbaum, Anja, Anne Kimmes, Joachim Kornelius, eds. Annual Report on English and American Studies (AREAS). 2012/2013. Vol. 43. Trier: WVT, 2012.

Holfter, Gisela, ed. The Irish Context of 'Kristallnacht': Refugees and Helpers. Trier: WVT, 2014.

Huber, Werner. James Stephens' frühe Romane: Rezeption - Text - Intention. Frankfurt: Lang, 1982.

. "I was Ireland...": Eine imagologische Studie zur irischen Autobiographie des 20. Jahrhunderts. Habilitationsschrift Paderborn, 1996.

Huck, Christian. Das Paradox der Mytho-poetik: Dichtung und Gemeinschaft in der irischen Literatur: Yeats, Heaney, Boland. Heidelberg: Winter, 2003.

- Fashioning Society, or, The Mode of Modernity: Observing Fashion in EighteenthCentury Britain. Würzburg: Königshausen \& Neumann, 2010.

Huppertsberg, Carla. Das Irland-Bild im Erzählwerk von Somerville \& Ross: Intention Gestaltung - Rezeption. Bonn: Bouvier, 1980.

"IASIL Bibliography Bulletin for 1996". Ed. Kellie Donovan Wixson. Irish University Review 27.2 (1997): 325-46, 348-59.

"IASIL Bibliography Bulletin for 2010". Ed. Beatriz Kopschitz Bastos. Irish University Review 41.2 (2011): 196-263.

"IASIL Bibliography Bulletin for 2014". Ed. Beatriz Kopschitz Bastos. Irish University Review 45.2 (2015): 1-66.

"IASIL Bibliography Bulletin for 2015". Ed. Beatriz Kopschitz Bastos. Irish University Review 46.2 (2016): 1-62.

Imhof, Rüdiger. Harold Pinters Dramentechnik: Gestalterische Mittel im Kontext des Gesamtwerks. Trier: WVT, 1976.

, ed. Alive Alive O! Flann O'Brien's At Swim-Two-Birds. Dublin: Wolfhound Press/Totowa, NJ: Barnes and Noble, 1985.

- Contemporary Metafiction: A Poetological Study of Metafiction in English since 1939. Heidelberg: Winter, 1986.

—, ed. The Playboy of the Western World, by J.M. Synge. 2 vols. Frankfurt: Diesterweg, 1987.

. John Banville: A Critical Introduction. Dublin: Wolfhound, 1989. ed. Contemporary Irish Novelists, Tübingen: Narr, 1990.

Jochum, Klaus Peter. Die dramatische Struktur der Spiele von W.B. Yeats. Frankfurt: Athenäum, 1971.

. W.B. Yeats: A Classified Bibliography of Criticism. Urbana: U of Illinois P, 1978.

Klein, Bernhard. Maps and the Writing of Space in Early Modern England and Ireland. London: Palgrave Macmillan 2001.

. On the Uses of History in Recent Irish Writing. Manchester: Manchester UP, 2007.

Kosok, Heinz, ed. Studies in Anglo-Irish Literature. Bonn: Bouvier, 1982.

- German Studies in Anglo-Irish Literature, 1972-82. Dublin: Goethe Institute and National Library, 1983.

. O'Casey the Dramatist. Gerrards Cross: Colin Smythe, 1985.

—. Short Plays from Ireland. 2 Vols. Frankfurt: Hirschgraben, 1989.

- Geschichte der anglo-irischen Literatur. Berlin: Schmidt, 1990.

-. "Irish Literature and Irish Studies in Germany". Deutsch irische Verbindungen: Geschichte, Literatur, Übersetzung / Irish-German Connections: History, Literature, Translation. Eds. Joachim Fischer, Gisela Holfter and Eoin Bourke. Trier: WVT, 1998. 21-32. 
Liu, Xialin. Going Down the Flow of Life: A Transcultural, Ecocritical Approach to Joyce's Ulysses and Twain's Huckleberry Finn. PhD thesis. University of Augsburg, 2015.

Lobsien, Eckhard. Der Alltag des Ulysses: Die Vermittlung von ästhetischer und lebensweltlicher Erfahrung. Stuttgart: Metzler, 1978.

- Die Antworten und die Frage: Funktionen der Literatur - Der irische Roman 1800 bis 1850. Würzburg: Königshausen \& Neumann, 2014.

Lubbers, Klaus. Geschichte der irischen Erzählprosa: Von den Anfängen bis zum ausgehenden neunzehnten Jahrhundert. München: Fink, 1985.

-. Modern Irish Short Stories. 2 Vols. Frankfurt: Hirschgraben, 1985.

Meenan, Katherine, ed. Germany: Looking In, Looking Out. Paper of the Institute of International and European Affairs (IIEA) 17 December 2015. 25 July 2017. Phttp://www.iiea.com/publications/germany-looking-in-looking-out.

Middeke, Martin and Peter Paul Schnierer, eds. The Methuen Drama Guide to Contemporary Irish Playwrights. London: Methuen, 2010.

Nowak, Helge. Literature in Britain and Ireland: A History. Tübingen: Francke, 2010.

O'Reilly, Claire and Veronica O'Regan, eds. Ireland and the Irish in Germany: Reception and Perception. Baden-Baden: Nomos, 2014.

O'Toole, Fintan. "Introduction: On the Frontier". Dermot Bolger. A Dublin Quartet. Harmondsworth: Penguin, 1992. 1-4.

Real, Hermann J. and Heinz J. Vienken. Jonathan Swift Gulliver's Travels. München: Fink, 1984.

Reichert, Klaus, Fritz Senn, Dieter E. Zimmer, eds. Materialien zu Joyces Dubliner. Frankfurt: Suhrkamp, 1969. , Fritz Senn, eds. Materialien zu James Joyces Ein Porträt des Künstlers als junger Mann. Frankfurt: Suhrkamp, 1975.

Rennhak, Katharina, ed. Narrating Ireland in Different Genres and Media. Irish Studies in Europe 7. Trier: WVT, 2016. and Sandra Heinen, eds. Walter Macken: Histories and Stories. Forthcoming 2018.

Schoner, Ursula. Lady Morgans Irlandromane als Spiegel des angloirischen Identitätsproblems im Zeitalter O'Connells. Frankfurt: Lang, 1983.

Schrage-Früh, Michaela. Emerging Identities: Myth, Nation and Gender in the Poetry of Eavan Boland, Nuala Ní Dhomhnaill and Medbh McGuckian. Trier: WVT, 2004.

. Philosophy, Dreaming and the Literary Imagination. London: Palgrave Macmillan, 2016.

Sedlmayr, Gerold. Brendan Kennelly's Literary Works: The Developing Art of an Irish Writer, 1959-2000. Lewiston: Edwin Mellen P, 2005.

. The Discourse of Madness in Britain, 1790-1815: Medicine, Politics, Literature. Trier: WVT, 2011.

Tonning, Erik. "I am not Reading Philosophy': Beckett and Schopenhauer". Beckett/Philosophy. Eds. Matthew Feldman and Karim Mamdani. Stuttgart: Ibidem, 2015. 75-102.

Wagner, Hans-Peter. A History of British, Irish and American Literature. Rev. ed. Trier: WVT, 2010.

Weimer, Martin. Das Bild der Iren und Irlands im Punch 1841-1921. Frankfurt: Lang., 1993.

Zach, Wolfgang and Heinz Kosok, eds. Literary Interrelations: Ireland, England and the World. Vol 1: Reception and Translation, Vol. 2: Comparison and Impact, Vol. 3: National Images and Stereotypes. Tübingen: Narr, 1987. 


\section{Organizations and Institutions Mentioned}

Asociación Española de Estudios Irlandeses. http://aedei.es/

British Asssociation for Irish Studies (BAIS). https://bairishstudies.wordpress.com/

Centre for Irish-German Studies Limerick. http://ulsites.ul.ie/irishgerman/.

Culture Ireland. http://www.cultureireland.ie/

Ehrenpreis Centre for Swift Studies. http://www.uni-muenster.de/Anglistik/Swift/

European Federation of Associations and Centres of Irish Studies (EFACIS).

http://www.efacis.eu/site/index.php

German Association for Anglophone Postcolonial Studies (GAPS). http://www.g-a-ps.de/about.htm

Irish Film Institute (IFI). ifi.ie

Irish Itinerary. http://www.efacis.org/irish-itinerary/

Leuven Centre for Irish Studies (LCIS). https://www.arts.kuleuven.be/lcis

Nordic Irish Studies Network (NISN). http://nisnetwork.org/

SOFEIR, Societé Française d' Études Irlandaises. https://www.sofeir.fr/en/

University of Liverpool Institute of Irish Studies. https://www.liverpool.ac.uk/irish-studies/

Vienna Centre for Irish Studies. http://anglistik.univie.ac.at/research/centre-for-irish-studies/

Received: 30 October $2017 \quad$ Revised version accepted: 21 January 2018

Jochen Achilles is Professor emeritus of American Studies at the University of Würzburg, Germany. His authored book publications include a study on the development of Sean O'Casey's plays in the context of modern drama and a book on the interface between the gothic tradition and psychological fiction, focusing on Sheridan Le Fanu. He co-edited numerous books, among them studies on contemporary Irish dramatists and representations of evil in fiction and film. Most recently, together with Ina Bergmann, he co-edited Liminality and the Short Story: Boundary Crossings in American, Canadian, and British Writing, published by Routledge in 2015. His research interests include liminal cultural identities, the American short story, African American and Irish drama. In all of these areas he has published many articles.

Jochen.achilles@uni-wuerzburg.de 